\title{
Alienated and disenchanted youth: A study of comparison and contrast between Holden Caulfield and Charlie Kelmeckis
}

\author{
Shuvro Das
}

M.A. in English Literature and Cultural Studies, Department of English, Jahangirnagar University, Savar, Dhaka-1342, Bangladesh

\begin{abstract}
Juxtaposing two of the most familiar young adult literary characters, this paper tries to read the comparison between the two characters of two different periods with different backgrounds. Both these characters show a few common character traits, such as- loneliness, shyness, and post-traumatic stress disorder, to name a few. This paper tends to explore the connection between the nature of their respective traumatic youths through the lens of Freudian psychoanalysis. Holden and Charlie are two conjoined characters linked by their aloofness and oddities-this very paper puts an effort to understand why they want to 'observe the world' rather than 'participate actively. 'Finally, this paper delves into inquiring if these traumatic youths represent the universal condition of the struggling youngsters and their self-inflicted ostracism from society.
\end{abstract}

Keywords - Young adult, loneliness, alienation, traumatic, youngsters, disenchantment.

\section{INTRODUCTION}

This paper critically scrutinizes the characteristics of Holden Caulfield and Charlie Kelmeckis to understand the significance of their alienation inflicted identity and it is affect to show how their disenchantment, isolation, detachment, fears of betrayal and abandonment incorporate in disastrous effect to make themselves nonconformists and the a tendency to escape from reality and living in their own constructed world. Both are confused about life and existence, making them prone to delirium and disintegration. It also shows the universality of the problems they face and these two young adults are no stranger to the youths all over the world, sharing the same dilemma, despair, and crises.

It has always been a topic of dispute whether Steven Chbosky's The Perks of Being aWallflower is inspired by J.D. Salinger's The Catcher in the Rye or not. It is also said that the isolated and exterminated youth of Charlie might have a connection with Holden's. It is, therefore, essential to find out the correlation between the two characters, if any. Furthermore, last but not least, their segregated life and struggling youth portray the harsh but honest picture of their respective, representative societies. To find out a more outstanding picture of the disillusioned and alienated youth of the whole world based on these two characters could be a good reason to work on this research.

Holden and Charlie: The alienated societal outcasts Distraction, Introversion and flaws of Holden and Charlie

Holden Caulfield of The Catcher in the Rye and Charlie Kelmeckis of The Perks of Being a Wallflowertwo adolescents are suffering from the angst and ambivalence of their puberty stages. Holden is from the 1940-50s, exhausted and frustrated with life in post-WWII America. While Charlie is a teen in the early 1990s, growing up in a rapidly progressing America which excels in communication and technology. They are searching for their own identity, their rightful places in society, and approval, which might help them to be organized and shape in a better way. Heavily showing the symptoms of introversion, flawed and defeated idealism, disillusionment, and a contradictory desire for isolation and intimacy, their inner psyche is preferably at a loss of what to do and how to correspond or act accordingly. Perplexed by the vagueness of the transition from childhood to adulthood, they have been victimized by chaos, confusion and goes through the irrepressible phases of anarchy and disorder. Everything seems to be blur enough to create a hallucination that distracts them from the track and morbidly 
affecting their psychology. Nonetheless, they need to confront that they have been assigned.

Something inexplicable prevents them to 'participate.' As a result, they are unable to fit in or actively participate. Partly, they also hinder themselves from being proactive. Trying simultaneously to live life and alleged attempts to escape from it, both are forced to endure their status as the outcasts.

\section{Holden as a cold, disturbed, and confused youth}

Holden Caulfield, the middle child of a well-to-do suburban New York family, gets kicked from Pencey Preparatory high school because of default. He is seventeen years old, and this is the fourth incident of getting forced out of school. His topsy-turvy relationship with schools suggests the inner restlessness and disrespect towards ongoing social conventions. Holden is a cynical person, seldom gets emotionally attached to anybody. A lifelong practitioner of solitude and aloofness, he suddenly finds himself in profound discrepancies in life. The transition of adolescent life visibly makes him suffer the most. A loner and spectator rather than a participant, he fears emotional attachment hurts and leaves a scar in mind.

"Don't ever tell anybody anything. If you do, you start missing everybody." (Salinger 115).

The harsh but unavoidable truth about his life is that he can never settle down, neither in his life nor educational institutions. Pencey remaining his fourth school to get dropped out, his mind is very unsettling. Holden hardly seems to be a boy who is threatening or vindictive; his schooling

is always interrupted. The startling this is that he hardly feels any emotional attachment for his previous schools or the mates he had studied with.

"I was trying to feel some kind of a goodbye. I mean I've left schools and places I didn't even know I was leaving them. I hate that." (Salinger 3)

Holden's existential crisis is mixed up with his reluctance to participate

Holden suffers from an existential crisis that frequently questions his life vis-à-vis the incidents he faces voluntarily or involuntarily. The bluntness of his life hurts him, prompting him sadden him. As he walks along the New York streets without any purpose or destination, it almost seems like life has deserted him, devoid of showing mercy. Holden is unknown to verbiage and relatively too passive to get mixed with others. He faces difficulties in showing any emotion to anyone rather than his favorite younger sister, little Phoebe. Despite his brave attempt to enter into the realm of 'experience' from 'innocence,' Holden is reluctant and eventually remains unable to part with what is considered to be his last connection to innocence. The delirium increases the dilemma of his mind and interrupts to become what he yearns to be.

The tendencies of avoidance, nonconformism, and observations of Charlie

CharlieKelmeckis is a fifteen-year-old boy from an insolvent family and is known to be an asocial. Suffering from social anxiety and personal problems, he writes letters to unknown recipients about himself, addressing all of them as 'dear friend.' Charlie is initially innocent and well-meant to everyone. He feels a kind of pleasure in detaching himself from being the participant, sticking to the role of a 'wallflower' or a superficial 'observer.'

Charlie is heavily caught between living his life and escaping it. As an adolescent, he finds it puzzling which life he should choose to live, the life of a child or that of an adult. He attempts to understand the world around him seldom tries to take part in and is substantially left heartbroken after getting rejected and dislocated. That causes him to regress socially and search for a way to renounce the world completely. He races for the right track, but the pavilion seems very far from his being.

Like Holden, Charlie does not confront his fear. Instead, he seems to be reflecting them through his thoughts and speeches. Lacking verbosity, he too afraid closeness, though initially. A profound thinker who is incredibly curious and cherishes inquisition; he prefers to ponder the choice of participation.

"I think the idea is that every person has to live for his or her own life and make a choice to share it with other people. Maybe that is what makes people "Participate." '. (Chobsky 182).

\section{Fear of non-acknowledgment and unacceptability}

Charlie possesses a self-conflicting attitude towards his isolation. He is aware that he has awkwardness and struggles to fight it off. Being concerned about his flaws and regularly questions his character, almost blaming himself for his exclusion. $\mathrm{He}$ is way too pristine that maximizes his vulnerability. Not thoroughly innocent, Charlie sticks to the belief that one day he will be redeemed. His redemption will pay all the dues.

"He is a wallflower. You see things. You keep quiet about them. And you understand". (Chbosky 47).This very 
statement sums up Charlie quite well. The main reason behind his exclusion is his anxiety about how others will accept them. His self-inquisition bears the testimony of accepting his flaws comprehensively.

\section{Morbidity, disruptions, and dilemma}

Disruptions and disasters are the main traits that alienate Holden and Charlie from their respective societies. Speculations over their behavior suggest that they are partially responsible for their being outcasts, and partially the society hinders them from participating actively, in which they live. They are suspicious, but their coldness owes much to the antagonistic fervor of the societal regulations and norms. Holden suffers from his disillusionment as he has been subjected to the harsh reality of being a misfit in society. His sufferings are purported by the psychological stances which are nonetheless, morbid and represent a kind of insanity. The antithetical thinking and eccentric rationalism that he nurtures play their respective parts to his cynicism against the society. Moreover, his existence as a young adult in the aftermath of WWII adds to this dilemma, broken sense of society. The premature exposure to the harsh realities of life, namely being a dropout, makes him vindictive to adopt and nurse the rules through which he could become a 'normal being.'

\section{Holden's vulnerability}

The brief presence of sexuality and sexual urge in his life suggest that his adolescent mind craves for bodily pleasure like his contemporaries. The prostitute and his pimp, Maurice, once again teaches him the harshest truth about survival with a heavy blow that only the fittest will survive, which suggests the vulnerability of Holden. Jane Gallagher and Sally Hayes represent the admiration he holds for the women but remains a failure to establish a deep emotional bond with none. His lack of belief and unsettled mind make him pay a lot. Phoebe gives him some kind of emotional shelter. Still, she is a child and in a state of pure innocence. However, she is the only character to whom the misfit Holden can be intimate with.

\section{Charlie as a naïve youth}

On the contrary, Charlie is alienated as he is a character who chooses life to live in a distinct way. Making friends like Sam and Patrick is a coincidence, as he emphasizes being a spectator. He is far less flawed than Holden as he is well aware of his lacking and can accept them readily. Unlike Holden, he does not believe in blame-shifting or thinking himself to be superior. Charlie is too naïve, and this habit leads him to the state of becoming a wallflower as he is.

\section{Charlie-The reader, not the speaker}

He seeks refuge in books and adores them the best he could. He often mixes himself with the characters in the books he reads, and this gives him immense pleasure.

"It is strange because sometimes I read a book. Moreover, I think I am the people in the book" (Chbosky, 36).

\section{The self-awareness of Charlie}

Though he possesses anti-heroic qualities, he has a specific command over them. He indeed helps Patrick, when a group of students beats him. The intricate combination of immaturity and innocence and their rejection towards conformity prompt the society to misunderstand and misinterpret him and label as an outcast. Nevertheless, he remains true to himself. In a bottle spinning game of truth or dare, he is assigned to kiss the most beautiful girl; he kisses Sam in front of Mary Elizabeth, to whom he is in a romantic relationship. As a result, this relationship ends in a catastrophic effect. Moreover, Charlie's admiration of Sam comes in the light.

\section{Alienated and disenchanted youth Degeneration}

It refers to a process through which something gets worse as the progression of days. Holden isfrom the backdrop of the aftermath of WWII. The very notion of the American dream gets shattered and distorted as the great depression and other obstacles hit the USA. The rottenness of this dream depicts through the character of Holden as he can never be the person whom the society wants him to be. Distortion is in every nook and corner of the society, and by confronting them, Holden has degenerated.

"When you are not looking, somebody'll sneak up and write 'fuck you' right under your nose.' (Salinger 110).

Charlie lives in society, hardly values the emotions of others, and seldom shows any

compassion. Humanistic qualities are almost absent there. It only seeks material gain, and technological prosperity is a surplus of it. Being a compassionate person, Charlie suffers from a state of almost degeneration. The materialistic view of society is coupled with Charlie's loathing of confrontation.

"I am very interested and fascinated by how everyone loves each other, but no one each other." (Chbosky 64).

\section{Disruption and disgust}

Holden is disgusted and disrupted by the 'phoniness' of the people. Phoniness refers to the disgust which repels him the most. $\mathrm{He}$ is allergic to it because phony nature is very annoying, and almost all his life he has found is tough to put up with them. One such is Ward Stradlater, his dorm mate, 
who always talks bogus, and the fakeness he displays makes Holden hold further antipathy towards others.

"People are always ruining things for you." (Salinger 47). Charlie is disgusted by way of the reaction of others; mostly, it reveals very well when his friend Patrick is vehemently bullied and physically abused because of his sexual orientation. Anger is very rare in him; still, she beats up the bullies, being disgusted with the fact that a person does not have the right to express his feelings. Charlie holds a grudge towards them who are not real, much like Holden.

"Try to be a filter, not a sponge" (Chbosky, 178).

\section{Delirium}

At the end of the novel, Holden is admitted to a sanatorium or mental asylum, which suggests his confrontation with mental issues and eventually succumbing to it. $\mathrm{He}$ is disturbed and, to some extent, tortured by the conventional and cold treatment of him by almost everyone around him. Finding nobody close to him and life is without any intrinsic value. He is cracked, broken, and finally, delirious. Perilous and upbeat as he is, his delirium sends him to the point of mental breakdown.

"I don't know what I was running for-I guess I still feel like it" (Salinger 3).

Charlie is also sent to a mental asylum after trying to commit suicide as he is haunted by the trauma of his childhood and the incidents of his surroundings. A sense of brokenness pervades him, and the tiny pieces of himself testify about his insanity. Eventually, he is saved from his deteriorating mental health and is no longer prone to psychotic disorders.

\section{Fragmented psychology}

Both Holden and Charlie suffer from fragmentation, and that affects their respective psychology vehemently. Holden is entangled in the labyrinth of his conscience and held a captive in the society he lives. Unable to solve the puzzle of life and existence, the fragmented sense gives him an idea of overwhelming hatred. $\mathrm{He}$ is embittered over almost everything, and as a consequence, his lack of drive to participate takes place.

Charlie has almost similar problems though less acute, yet his fragmented psychology puts him into a maze from where he can hardly be out and lead a life which is known as 'normal.' His fragmentation is worth poignancy as it eventually sticks his broken pieces together.

\section{Searching for the self}

Holden searches for himself in every matter or affair of his life, no matter how trivial or irrational it might look.
Desperate to establish his 'self,' he emphasizes ongoing through the phase of 'experience' from his cherished 'innocence'; but collapses between what to adopt and what to leave behind. His quest for self is negated as he finds nothing but a big hollowness.

Charlie also searches for his self by his self-inquisition and questioning of his somewhat eccentric nature. Sometimes he is swayed by the thought of why he is so different from everyone. Awareness of his self-arises when he is somehow socialized in 'the island of the misfit toys' and gets a picture of how his life is or should be via this group of friends.

\section{Disenchantment}

Holden and Charlie are both disenchanted. It means they are no longer prone to the enchantments. Holden's disenchantment takes place due to his exposure to the realities of a flawed society where the material gain has been prioritized. Hit by WWII, the society is yet to be flourished, and lacking compassion, emotion, and values, youth like Holden are disenchanted. Society tried to keep them in the false enchantment or illusion but failed as realization takes place very harshly.

\section{Trauma of the past}

Holden and Charlie often encounter the traumas of their respective pasts. Holden can never get over with the death of his younger brother, Allie. The decadence he faces regarding this issue leaves a ghastly and morbid impression on him. Holden talks to his dead brother whenever he is sad, and the death stimulates his choice of being an alienated person. The accident still haunts him as Allie used to be very close to him.

Charlie has been abused as a child by his dear aunt, Helen. This horrific incident makes him withdraw from having sexual relationships; first, with Mary Elizabeth a then Sam. Aunt Helen used to be very sad and tried to commit suicide as she had been deceived by many of his boyfriends and abused Charlie to fulfill her repressed desire to be with a man. She dies while buying Charlie a Christmas gift, and he holds himself responsible for this mishap. Charlie attempts to suicide by haunted with this nightmarish memory, which has become too much to handle for him.

\section{Reluctance to the mainstream}

The fears of abandonment, unacceptance, traumas, awkwardness a and 'less talking more observing' personality play their respective parts in their growing sense of reluctance for the mainstream. They hate superficiality and fakeness, and society provides them with ample of these. So, 
they stick to their reluctance in mingling with the so-called 'mainstream.'

\section{Problems faced by youngsters and the universality of their alienation}

Alienation and disenchantment are two of the recurrent features of the youngsters. In this age of late capitalism and technological peak, human emotions are somewhat neglected, and nobody is seemingly interested in the problems the youth face. In the age of puberty or adolescence, every youth goes through the states of emotional imbalance and both physical and mental turmoil. They get quite vulnerable and prone to outbursts. They dwindle between what to choose and what to leave. No fixity comes into being. The quest for knowing the unknown, discoveries, and emotional unsettlement is not very rare.

They hardly find any meaning of life and suffer from an existential crisis. Befuddlements are natural traits, and they hardly find anything that could explain to them about life, love, bonding, and so on. As a result, they deviate from the track and become alien with their own life and society. As suffered by Holden and Charlie, their disillusionment gets the better of themselves

\section{CONCLUSION}

Holden Caulfield and Charlie Kelmeckis are representatives of two very different eras. Still, they face similar types of problems. Their life takes similar turns, and nevertheless, consequences are almost the same. Disintegration, disapproval of the society, disillusion, renunciation of the world, confusion, existential crisis, dilemma, decadence, trauma, fears of denial, abandonment, intimacy, and hatred towards the falsified world knot their threads together and play as root causes their alienation and disenchantment. Representing two different ages and yet having issues so similar testifies the universality of their alienation and disenchantment.

By comparing two young-adult people of two distinctive ages, the paper attempted to juxtapose the universality of the alienation of youth in the light of these two characters. Further study could help search for the solution to the problem faced by a thousand young adults, who are very important to the progression and prosperity of society. If the problem is solved, the youngsters will be free from the 'alienation effects.'

\section{REFERENCES}

[1] Chbosky, Stephen. The perks of being a wallflower, New York: Pocket Books, Simon and Schuster Inc, 1999. PDF.

[2] Salinger, J.D. The Catcher in the Rye. Boston: Little, Brown, 1951. PDF.

[3] "Outcast In Perks Of Being A Wallflower English Literature essay.”N.p. $\quad$ n.d. $\quad$ Web.21 <http://UKESSAYS.com/>

[4] "Compare and contrast of Chalie and Holden."N.p. n.d. Web. 21 Feb. 2016. <http://StudyMode.com/>

[5] Anderson, Rus. "The Perks of Being An Open Minded Holden Caulfield". The Fremd High School English Ning, 12 Jan.2013. Web. 21 Feb. 2016. <http:// fremdeng.ning.com/> Murphy, Steve. "Comparison between Two Teenagers in Different Times.”N.p. 10 Oct. 2005. Web. 21 Feb. 2016. <http://BookRags.com/>

[6] Kathryn. "Book Reviews: Perks and Catcher: Differences of Narrative Styles." Nine Pages, 7 Jul.2012. Web. 21 Feb.2016. < http://wordpress.com/>

Earky, Sherry. "The Perks of Being a Wallflower By STEPHEN CHBOSKY.”N.p. 24 Sep. 2012. Web. 21 Feb. 2016. <http:// BREAKPOINT.org/>

[7] " A Psychoanalytic Interpretation of The Catcher In The Rye.”N.p., 25 Sep.2009, Web. Feb 21, 2016. < http://Studentacademichelp.blogspot.nl/>

[8] Aubry, Timothy. "The Catcher in the Rye: The Voice of Alienation.'Institute of American History, N,d. Web.21 Feb.2016. < http://Gilderlehrman.org/>

[9] Thiruvalluvan, R. "The Theme Of Alienations In The Novels Of J.D.Salinger." The Indian Review of World Literature in English, Vol 3, No. 1-Jan 2007. Web. 21 Feb.2016. $<$ http://worldlitonline.net >

[10] Steigerwald David. "Where have you gone, Holden Caulfield? Why We Aren't Alienated Anymore?". Department Of History, Vol 4, Issue 4-Jan 2011. Web. Feb 21.2016. <http://origins.osu.edu/>

Esseau-Thomas, Chrys-Michel. "Perks is a modern Catcher in the Rye". The Panther, 19 Nov, 2011. Web. Feb 21.2016. $<$ http:// thepantheronline.com/> 